\title{
Fengsel eller frihet: \\ Noe om reaksjonsvalg i norsk strafferett
}

\author{
Førsteamanuensis, ph.d. Morten Holmboe, \\ Politihøgskolen, Norge ${ }^{l}$
}

\begin{abstract}
The grounds for a given society's punishment of offenders has a long history of discussion.

In Norway, deterrence is seen as the basis for the criminal justice systemboth in general and as a guide in choosing between types of punishment in concrete cases. General deterrence theory suggests that people might abstain from crime either because of an assessment of its potential risks or because the use of punishment leads to a general habit of obeying the law - and that people rest assured that justice is done, leading to a sense of safety in society.

If a person charged has made a complete confession, the court shall take this into account when passing sentence. This rule is designed to encourage the guilty to confess, but it is possible that innocent defendants are sometimes tempted to confess in order to avoid harsher punishments.

When a fine is imposed, a sentence of imprisonment is executed if the fine is not paid on time. The authorities begin by trying to get the money from the defendant's legal assets. Seventy-seven percent of the defendants who are supposed to go to prison pay the fine. Does the money come from friends and relatives or from crime?

In 2010, the punishments for several types of crime were increased. Given the theory of deterrence, it would be reasonable to assume that the legislators hoped that longer sentences would lead to less crime. Yet when assessing the need for more prisons, there is no discussion of the value of deterrence.

The theory of general deterrence is also applied in concrete cases. In certain types of cases there are established guidelines for when to apply prison. Nonetheless, general deterrence has been given different weight in comparable areas, e.g., fraud against insurance companies versus fraud against the social services.

Certain rules concerning the rights of the convict are based on the kind of punishment (prison or not) that was meted out, e.g., the right to inheritance or
\end{abstract}


insurance. Since a defendant's personal situation can have a considerable bearing on punishment, I question whether the rules should be more flexible. ${ }^{*}$

\section{Sammendrag}

«Hvorfor straffer vi?» er et grunnleggende spørsmål. I forarbeidene til straffeloven av 2005 uttales det at man ikke straffer for å gjengjelde handlinger, men for å avverge fremtidig kriminalitet og sikre den sosiale ro i befolkningen. Særlig allmennprevensjonen løftes ofte fram, men denne kan bety flere ting: At potensielle lovbrytere avskrekkes, at straffen fører til en «vanemessig lovlydighet» og til at folk flest føler seg trygge. En henvisning til «allmennprevensjonen» sier derfor lite om hva slags konsekvens en streng straff vil få.

I artikkelen drøfter jeg noen sider ved lovgiverens konkrete valg av strafferettslige regler.

Reglene om tilståelsesrabatt skal tjene til å få skyldige mistenkte til å tilstå og dermed forkorte saksbehandlingstiden. Det er likevel lite drøftet i straffelovens forarbeider om en aktiv bruk av tilståelsesrabatt kan friste også uskyldige mistenkte til å tilstå.

Når noen ilegges en bot, fastsettes det en subsidiær fengselsstraff som skal få den botlagte til å legge godviljen til og betale boten. Statens innkrevingssentral forsøker først å ta dekning i skyldnerens eiendeler, lønn eller trygd. Først deretter kalles den botlagte inn til soning. Spørsmålet er om ordningen kan føre til at andre enn den botlagte betaler boten, eller til mer vinningskriminalitet.

I 2010 ble strafferammene og straffutmålingen for en del lovbrudd kraftig skjerpet. I forarbeidene er det gjort beregninger av hvor mange ekstra fengselsplasser som ville behøves, men ikke drøftet om kraftige straffskjerpinger kunne føre til at kriminaliteten gikk ned. Det kan derfor spørres om lovgiverne selv har trodd på teorien om at økte straffer kan føre til nedgang i kriminaliteten.

Høyesterett har gjerne begrunnet valget mellom ubetinget fengsel og mildere reaksjoner med prevensjonssynspunkter.

På enkelte områder (for eksempel trygde- og forsikringsbedragerier) er det etter hvert etablert en praksis der grovheten av den straffbare handling blir avgjørende for reaksjonsvalget. Grensen trekkes likevel forskjellig for sammenlignbare lovbrudd - under henvisning til allmennprevensjonen.

* Title in English: Prison or not? On the assignment of punishment under Norwegian Criminal Law. 
I en human strafferettspleie vil ikke bare det straffbare forholds karakter avgjøre reaksjonsvalget, men også gjerningspersonens personlige forhold. I avhandlingens siste del behandler jeg en del regler som knytter følger til reaksjonsvalget (bl.a. anmerkninger på politiattester, tap av rett til arv og forsikringsytelser). Her er reglene temmelig skjematiske, og jeg reiser spørsmålet om konkret reaksjonsvalg bør avgjøre lovbryterens rettsstilling på andre rettsområder.

\section{Innledning}

Når et velferdssamfunn velger å påføre noen av sine medlemmer et onde med det formål at det skal være et onde, må det begrunnes. Spørsmålet er ikke rent akademisk: Den begrunnelsen man bygger på, kan ha betydning for hvordan man straffer.

Det vil ikke si at en dommer grunner over straffeteoriene hver gang han eller hun utmåler straff. I praksis dreier straffutmåling seg ofte om å finne riktig straff $\mathrm{i}$ henhold til praksis og vanlige straffutmålingsnormer. ${ }^{2}$ Også for lovgiveren som skal fastsette strafferammen i det enkelte straffebud, vil tradisjonen ha stor betydning. Men det er nødvendig å stille seg spørsmålet: Hvorfor straffer vi, og hvordan får straffeteoriene (eller straffeideologiene) $)^{3}$ utslag i praksis?

Norges Høyesterett behandler forholdsvis mange saker om straffutmåling, og disse sakene vil derfor tjene som en slags institusjonalisert historiefortelling til veiledning for andre rettsanvendere. Også Høyesterett vil følge sin tidligere praksis, men det pågår både en rettsavklaring og rettsutvikling gjennom Høyesteretts praksis. I en del tilfeller må Høyesterett derfor ta stilling til hvor grensen bør gå mellom forskjellige reaksjoner. Der man ikke har en omfattende praksis, eller nye momenter er kommet til, kan de grunnleggende ideene om straffens formål ha betydning for reaksjonsvalget.

Den mest inngripende reaksjonsformen er frihetsberøvelsen. For de mest alvorlige lovbruddene vil en fengselsstraff bli forholdsvis lang, og dermed også inkapasitere lovbryteren og begrense risikoen for gjentagelse i soningstiden. Men i Norge løslates nær 2/3 av de domfelte før det er gått 60 dager. ${ }^{4}$ Så korte straffer gir liten inkapasiteringseffekt, og det er antagelig sjelden kriminalomsorgen rekker å gjennomføre omfattende rehabiliteringstiltak i løpet av en så kort soningstid.

Valget mellom ubetinget fengsel og mildere reaksjoner kan derfor kaste lys over straffens signalfunksjon, og hvordan lovgiveren og domstolene trekker grensen mellom reaksjonene. Disse spørsmålene har jeg søkt å drøfte i min ph.d.avhandling, som i februar 2016 ble forsvart ved Det juridiske fakultet, Universite- 
tet i Oslo. ${ }^{5}$ Tidsskriftets redaktør har bedt meg om å skrive en artikkel der jeg gir en oversikt over de viktigste funnene i avhandlingen.

\subsection{Prevensjonsteoriene i norsk strafferett}

I hvert fall siden innføringen av (den nå opphevede) straffeloven av 1902 har det vært den bærende idé i norsk strafferett at straff ikke i seg selv kan begrunnes med gjengjeldelse, men med en virkning. Straffen skal peke fremover og føre til et ønsket resultat. ${ }^{6}$

Straffeloven av 2005, som erstattet straffeloven av 1902, bygger på en rekke utredninger og tre lovproposisjoner. Det hele begynte med den såkalte Kriminalmeldingen, ${ }^{7}$ som ble oppfattet som et radikalt kriminalpolitisk dokument i sin tid. I denne stortingsmeldingen foreslo Regjeringen nedsatt en straffelovkommisjon som skulle utarbeide en ny straffelov. Kommisjonen ble nedsatt i 1980 og avga en rekke delutredninger fram til 2002. ${ }^{8}$ Deretter utarbeidet Justisdepartementet tre lovproposisjoner i årene 2004 til 2008. ${ }^{9}$ Straffeloven ble vedtatt i tre etapper fra 2005 til 2009. Loven ble satt i kraft 1. oktober 2015..$^{10}$

I Kriminalmeldingen ble det lagt til grunn at prevensjonsteoriene ikke lenger ga noe fullgodt svar på spørsmålet om hvorfor vi straffer. Stortingets justiskomité var derimot skeptisk til dette standpunktet. Straffelovkommisjonen la allerede tidlig $\mathrm{i}$ arbeidet til grunn at prevensjonsteoriene ga det beste uttrykk for hvorfor man straffer. ${ }^{11}$ I proposisjonen til den nye straffelovens alminnelige del ønsket regjeringen å drøfte straff mer prinsipielt. Departementet gikk såpass langt som til å fremholde at gjengjeldelse ikke kan være en del av straffens formål. Det ble likevel erkjent at prevensjonsteoriene også omfatter hensynet til «den sosiale ro», som bærer trekk av gjengjeldelsen med seg. ${ }^{12}$ Stortinget tok ikke prinsipiell avstand fra dette utgangspunktet.

Diskusjonen dreide seg mer om i hvilken grad lovgiveren burde gi domstolene detaljerte retningslinjer om straffutmålingen. Her så Stortinget - kanskje ikke overraskende - annerledes enn Straffelovkommisjonen på behovet for tydelige signaler fra lovgiveren. ${ }^{13}$ Ved vedtagelsen av lovens spesielle del ble minstestraffene $ø$ kt for en del lovbrudd, samtidig som det i forarbeidene ble gitt temmelig detaljerte retningslinjer for straffenivået for typiske overtredelser.

I nyere norsk strafferettsteori har det vært problematisert at straffen prinsipielt begrunnes med nyttehensyn. ${ }^{14}$ Trekkes henholdsvis gjengjeldelses- og prevensjonsteoriene til sin ytterste konsekvens, blir forskjellene store. I praksis vil resultatene ikke nødvendigvis bli så ulike. Det prinsipielle spørsmålet er likevel: Skal man straffe fordi det er nyttig, men begrense straffen utfra hensynet til rettferdig- 
het, humanitet og proporsjonalitet? Eller skal man straffe proporsjonalt, men begrense straffen til hva som er nyttig?

Straffens formål kan vektes forskjellig etter hvilket nivå av strafferettssystemet man vurderer. Dette er en kjent diskusjon i Sverige og Finland, der man tar utgangspunkt $i$ at lovgiveren fastsetter straffetrusler ut fra en nyttevurdering. I den enkelte sak skal dommeren derimot ikke se hen til allmennpreventive synspunkter, men til hva som er riktig straff i den enkelte sak. ${ }^{15}$

Denne distinksjonen er ikke ukjent i rettsfilosofien. For eksempel tok John Rawls opp distinksjonen i et av sine tidlige arbeider. ${ }^{16}$ I Danmark tok Alf Ross opp en lignende problemstilling, men møtte motbør fra Johs. Andenæs. ${ }^{17}$ Det er noe omdiskutert hvor stor betydning Ross egentlig har hatt på strafferetten $\mathrm{i}$ Danmark. ${ }^{18}$ Men også i nyere teori vises det til Ross. ${ }^{19}$

Forarbeidene til straffeloven av 2005 berører spørsmålet om straffens formål kan variere på forskjellige områder og nivåer av rettssystemet, men uten å ville endre det historiske utgangspunktet i Norge: At domstolene kan legge vekt på straffens formål ved utmålingen av straff $\mathrm{i}$ den enkelte sak. ${ }^{20}$

Forhistorien til straffeloven av 2005 viser at forarbeidenes betoning av nyttehensyn som utgangspunkt når man vurderer straffens formål er godt forankret $\mathrm{i}$ den tidligere rettsoppfatningen, og således ikke er noe nytt. Det er dermed rimelig å betrakte uttalelsene i forarbeidene til straffeloven av 2005 som et autoritativt uttrykk for hvordan lovgiveren ser på straffens formål i vår tid.

Oppsummert kan hensynene formuleres slik:

- Straffesystemet skal bidra til å begrense kriminaliteten

- Rettferdighet, humanitet og proporsjonalitet begrenser hvor streng straffen skal være, og hvem den kan ramme

Hensynene kan dels brukes som rettesnorer for om noe skal kriminaliseres, hvilke strafferammer som skal gjelde og hva som skal være utmålingspraksis. Det er i og for seg rimelig å anta at en skjerping av et straffenivå isolert sett kan redusere kriminaliteten, men det er ut fra humanitetshensyn grenser for hvor strenge straffene kan være. Men selv om man utelukkende tar hensyn til straffens formål, er det grenser for hvor streng straffen bør være. For det første kan et drakonisk straffenivå føre til at borgerne mistror myndighetene og ikke samarbeider med dem. Hvem ville ringe politiet for å hindre en venn i kjøre med promille hvis vennen ville få mange års fengsel? For det andre har straff åpenbare ulemper for de borgerne som straffes og ofte for deres pårørende, og er i mange tilfeller kostbar for samfunnet. 
Lengre soningstider gitt en uendret kriminalitet fører til økte kostnader til fengselsvesenet og gjerne lengre soningskøer. At borgere venter lenge på å sone korte fengselsdommer, letter ikke rehabiliteringen. Det kan også ha betydning om straffede med arbeid får så lange dommer at de mister sitt arbeid. Selv om man ser bort fra hensynet til de domfelte og deres pårørende, vil derfor straffens formål sette en grense for hvor lange straffene bør være. I tillegg kommer at en begrensning av kriminaliteten også har et formål: Å skape et samfunn der folk føler seg trygge. Opplever samfunnsborgerne at en forholdsvis uskyldig feil kan føre til streng straff, vil de kanskje passe ekstra godt på så de ikke bryter loven, men neppe føle seg tryggere.

Men selv om man skulle ha en oppfatning om at et visst straffenivå ville redusere kriminaliteten, krysses hensynet til straffens effektivitet av hensynet til humanitet, rettferdighet og proporsjonalitet. Det er her verd å trekke inn også de grunnleggende prinsipper i straffeprosessen. ${ }^{21}$

Prevensjonsteorier vil altså prinsipielt bruke hensynet til humanitet, rettferdighet og proporsjonalitet som justerende prinsipper, mens gjengjeldelsesteorier vil tendere mot å anføre disse prinsippene som begrunnelse for straff. Man kan i og for seg tenke seg at tilhengere av gjengjeldelsesteorier kan trekke inn prevensjonsteorier, men da som justerende prinsipper - for eksempel hvis det viser seg at en bestemt straffetrussel eller et straffenivå virker mot sin hensikt.

Et bilde på et strafferettssystem som bygger på prevensjonsteorier, kan være en politibil som skal kjøres fra Oslo til Trondheim. Hvis det ikke foreligger noen bestemt nødssituasjon, er det rasjonelt - og lovlig - å kjøre innenfor fartsgrensen. Det vil gi en stor sannsynlighet for å nå målet uten å kjøre ut, og lav risiko for at andre trafikanter skades. Er det grunnlag for å kjøre under utrykning, kan bilen kjøres betydelig raskere, men det går en grense for hvor fort og risikofylt man kan kjøre uten både å forspille formålet med turen og utsette andre for en uakseptabel risiko.

Et strafferettssystem som opererer med et drakonisk straffenivå, vil både ha vanskelig for å oppnå sitt primære formål (bilen kjører i grøften i stedet for å nå fram til Trondheim), og å unngå uakseptable skader på andre - selv om man skulle oppnå lavere kriminalitet (bilen kommer fram til Trondheim, men har skadet andre på veien).

Slike bilder sier ikke noe om hvor straffenivået bør ligge. Men de viser at rettssamfunnets oppfatning av hvor alvorlig kriminaliteten er, og av hvor mye straffen «virker», kan påvirke viljen til å ta i bruk strenge tiltak. 


\subsection{Allmennprevensjonen}

«Allmennprevensjonen» er et kjent uttrykk i strafferetten, men brukes med skiftende innhold. Til tider brukes det om «avskrekking»: Man tenker seg at en potensiell lovbryter overveier å begå et lovbrudd, men eksistensen av en straffetrussel og et tilstrekkelig strengt straffenivå kan få ham til å avstå fra lovbruddet (eller begå et mindre alvorlig lovbrudd som straffes mildere). En erfaren høyesterettsdommer skrev nylig slik om allmennprevensjonens betydning i konkret straffutmåling:

«Er det en situasjon der en kan vente at mulige gjerningspersoner lar seg motivere av rasjonelle tanker? Og - viktigere - vil det i tilfelle ha betydning for gjerningspersonens overveielser om han risikerer for eksempel fire år i fengsel istedenfor to år hvis han blir tatt? ${ }^{22}$

I den grad folk kjenner til - og lar seg influere av - straffenivået, er det kanskje viktigere hva slags reaksjon man får: At resultatet kan bli en ubetinget fengselsstraff, kan være viktigere enn lengden. ${ }^{23}$

Men uttrykket «allmennprevensjonen» brukes også om den mer indirekte følge av straffenivået: En konsekvent og streng håndheving av et straffebud gir et signal til folk om at en bestemt atferd er uakseptabel, og kan føre til en vanemessig lovlydighet. Den tradisjonelt strenge håndheving av forbudet mot promillekjøring i Norge har vært brukt som et eksempel på dette. ${ }^{24}$

Den antatte virkningen stanser likevel ikke der: En side av allmennprevensjonen antas i forarbeidene til straffeloven av 2005 å være at straffenivået bidrar til «den sosiale ro» - ved at folk ser at straffbare handlinger medfører reaksjoner. ${ }^{25}$ Dette hensynet er nært beslektet med det som kalles «den alminnelige rettsfølelse». At dette er tilfelle på det generelle plan, synes nokså klart. Men etter norsk rettstradisjon oppfattes det som legitimt å legge vekt på slike hensyn også ved den konkrete straffutmålingen. Her skiller norsk rett seg fra svensk og finsk rett, der allmennprevensjonen ikke oppfattes som et legitimt argument for dommerens valg av reaksjon i det enkelte tilfellet. Jareborg beskriver dette skillet slik:

«Lika illa ar det att dra in allmänpreventionen på domsnivån. Visserligen skall domen bidra till att lagens hot om straff inte är tomt, men varje enskild dom drunknar i mängden av tusentals andra: den har helt enkelt ingen allmänpreventiv effekt, och det finns ingen anledning varför den skulle ha det. Allmänpreventiva skäl kan på domsnivån innefatta endast att domen bör ingå i en serie av likartade domar som ligger på en viss straffnivå. Den enskilda domen ar allmänpreventivt ointressant, annat an som representant för en påföjdspraxis rörande en viss typ av brott. En viss allmänpreventiv verkan kan tillskrivas den samlade mängden domar, darför att den konkre- 
tiserar det allmänna straffhotets karaktär. Att statuera «exempel» genom att utdöma högre straff än brukligt är meningsfullt bara som en signal om ändrad praxis.» ${ }^{26}$

I Norge, hvor Høyesterett avsier en rekke dommer om straffutmåling som blir kjent for de underordnede domstolene og andre aktører i rettsvesenet, kan nok en straffskjerping i en enkelt dom få stor betydning for straffenivået i landet. I hvilken grad et skjerpet straffenivå fører til mindre kriminalitet, er et komplisert spørsmål som jeg ikke skal drøfte her. Men det er et annet problem med «allmennprevensjonen» som begrep: Uttrykket er så mangslungent at en ren henvisning til «allmennpreventive hensyn» sier lite om hva dommeren har lagt vekt på.

Ved at det kan være legitimt for en dommer å legge vekt på hensynet til «den sosiale ro», kommer også gjengjeldelsesteorier inn «bakveien»: Dommeren legger - tilsynelatende - ikke vekt på hensynet til en rettferdig gjengjeldelse, men på at «folk flest» vil synes en viss straff er nødvendig som rettferdig gjengjeldelse. Dette er det jo ikke så lett å si noe om, og det er rimelig å anta at dommeren vil se hen til sin egen rettsfølelse når han eller hun vurderer hva «den alminnelige rettsfølelse» tilsier. Man kunne riktig nok tenke seg at fagdommerne ville lytte til legdommerne som representanter for allmennheten. Til tross for at hensynet til «den alminnelige rettsfølelse» eller den sosiale ro antas å være et tillatt hensyn ved straffutmålingen, er det likevel få spor av at Høyesterett legger noen vekt på legdommernes syn - selv når retten bygger straffutmålingen på «den alminnelige rettsfølelse». ${ }^{27}$

\subsection{Individualprevensjonen}

I diskusjonen om straffens formål brukes gjerne «individualprevensjonen» som et offensivt argument: Når den straffbare handlingen først er begått, skal straffen bidra til å gjøre lovbryteren mer lovlydig. Dette kan gjøres dels gjennom straffens inkapasiterende virkning, dels ved at lovbryteren skremmes fra å gjenta lovbruddet og dels ved at lovbryteren internaliserer den normen han tidligere har brutt. Når lovbrudd er begått under påvirkning av rusmidler, kan en individualpreventiv effekt også oppnås dersom lovbryteren får hjelp til å få bukt med sitt rusproblem.

I praksis er det sjelden «individualprevensjonen» påberopes som argument for en strengere straff. ${ }^{28}$

Dette er likevel ikke uten unntak: I Rt. 2004 s. 365 fikk en tidligere straffedømt mann ubetinget fengsel i 120 dager for simpelt tyveri. ${ }^{29}$ Høyesteretts flertall - tre dommere - bemerket at en rimelig straff ville vært fengsel i 45 dager, men at det i denne saken var ønskelig med et lengre fengselsopphold for å etablere et behandlingsopplegg. Flertallet var derfor enig i at straffen skulle settes til fengsel i 120 dager. Flertallets standpunkt her er for så vidt i god harmoni med Høy- 
esteretts dom i Rt. 1976 s. 1217. Der fikk en 17-åring skjerpet straffen for grove tyverier og bilbrukstyverier fra 60 dager til åtte måneders fengsel for at fengselsmyndighetene skulle få tid til å etablere et behandlingsopplegg. Dommen har imidlertid vært kritisert. $^{30}$

Som oftest er det heller slik at individualprevensjonen brukes som argument for en mildere reaksjon (å unngå fengsel), eventuelt kombinert med programmer som kan hjelpe lovbryteren til å få orden på sin livsførsel. Eksempler på det første finner vi særlig der lovbrytere som er på vei ut av et narkotikaproblem, slipper fengsel for ikke å ødelegge rehabiliteringen. ${ }^{31}$ Eksempler på det siste finner vi for eksempel ved promilleprogram og narkotikaprogram som vilkår for betinget fengsel. Og ved de nye straffereaksjonene rettet mot unge lovbrytere, ungdomsoppfølging og ungdomsstraff, er det lagt til grunn i forarbeidene at man ved fastsettelsen av gjennomføringstiden ikke skal se hen til den straffbare handlings karakter så mye som lovbryterens konkrete behov for oppfølging.

I nyere teori har det vært gjort forsøk på å dele opp hensynene på en annen måte. For eksempel har Myhrer tatt til orde for en nifeltstabell der man skiller mellom primær-, sekundær- og tertialgrupper. ${ }^{32}$

\subsection{Gjenopprettende prosess}

I de senere år har det vært en økende oppmerksomhet omkring såkalt gjenopprettende prosess (restorative justice). ${ }^{33}$ I Norge er det særlig gjennom konfliktrådene man har søkt å gjennomføre disse ideene. ${ }^{34}$

Her er det ikke plass til å gjennomgå disse ideene og deres praktiske utslag. Jeg nøyer meg med å nevne at det ikke bare i Norge, men også internasjonalt er vanlig å anse Nils Christies artikkel Konflikt som eiendom som en grunnleggende tekst. ${ }^{35}$ Justisdepartementet skrev fra tidlig på 2000-tallet meget positivt om restorative justice, men disse utsagnene har i liten grad fått noe fotfeste $\mathrm{i}$ forarbeidene til straffeloven av 2005 - til tross for at man ved forberedelsen av loven ønsket å drøfte grundig hele grunnlaget for strafferettssystemet. Det er heller ikke mange spor i rettspraksis av at tanken bak restorative justice har fått betydning for straffutmålingen. Skal man plassere restorative justice (gjenopprettende prosess) innenfor de vanlige straffeteoriene, hører nok ordningen mest hjemme blant de individualpreventive hensyn. Men den har også en side til allmennprevensjonen i vid forstand: En vellykket gjenopprettende prosess kan bidra til den sosiale ro ved at lokalsamfunnet får en trygghet for at gjerningspersonen har forstått alvoret $\mathrm{i}$ sine handlinger. ${ }^{36}$

Det er mye godt å si om gjenopprettende prosess som idé. Men de samme problemer oppstår her som ved andre milde tiltak: Det vil lett oppstå en fristelse 
til å ta lettere på alminnelige krav til rettssikkerhet fordi man mener at tiltaket alt $\mathrm{i}$ alt er så godt for lovbryteren at man må gjøre det mest mulig effektivt. Den norske ungdomsstraffen, som ble innført i 2014 og bygget på ideene om gjenopprettende prosess, er etter mitt syn et eksempel på at god vilje ikke uten videre er tilstrekkelig. ${ }^{37}$

\subsection{Kort om de norske straffereaksjonene}

Etter norsk strafferett skilles det mellom straffer og strafferettslige reaksjoner. Straffene er listet opp i straffeloven av $2005 \S 29:^{38}$

«Straffene er

a) fengsel, jf. kapittel 6 ,

b) forvaring, jf. kapittel 7,

c) samfunnsstraff, jf. kapittel 8 ,

d) ungdomsstraff, jf. kapittel $8 \mathrm{a}$,

e) bot, jf. kapittel 9, og

f) rettighetstap, jf. kapittel 10 .

Når det ved fastsetting av straff er aktuelt å ilegge flere strafferettslige reaksjoner, jf. første ledd og $\S 30$, skal den samlede reaksjonen stå i et rimelig forhold til lovbruddet.»

Rekkefølgen av reaksjonene knytter seg ikke til reaksjonens alvor, men til hvor reglene er plassert i loven. Alle reaksjoner unntatt forvaring anses mildere enn ubetinget fengsel. I grensetilfellene er det ikke alltid like lett å si hva som er strengest: Prinsipielt er ungdomsstraff en strengere reaksjon enn samfunnsstraff. Men samfunnsstraff kan kombineres med ubetinget fengsel på inntil 60 dager. En slik kombinert dom vil antagelig ofte oppfattes som strengere enn en dom på ungdomsstraff, som ikke kan kombineres med fengsel. Vanligvis vil betinget fengsel oppfattes som mildere enn samfunnsstraff, men en dom på fengsel kan være delvis ubetinget, delvis betinget. En helt betinget dom kan også kombineres med tyngende vilkår, for eksempel promilleprogram eller narkotikaprogram. Det går selvsagt an å ta for seg én av disse milde reaksjonene og drøfte dommer der denne reaksjonen har vært diskutert. Det har jeg selv gjort i et par tidligere arbeider. ${ }^{39}$ Men når man vurderer grensen mellom ubetinget fengsel og mildere reaksjoner, må man ta i betraktning alle mildere reaksjoner. En gjennomgang av dommer om grensen mellom betinget og ubetinget fengsel gir ikke oversikt over praksis om bruk av samfunnsstraff. Men heller ikke sakene der samfunnsstraff har vært drøftet, gir det hele bildet - i en del tilfeller drøfter Høyesterett om det 
skal gis betinget eller ubetinget fengsel, uten å nevne samfunnsstraff som et alternativ. I avhandlingen søker jeg derfor å se på reaksjonssystemet som et hele.

Minstestraffen ved bruk av fengsel er 14 dager når ikke annet er bestemt i loven. ${ }^{40}$ Også ved vurderingen av om det skal gis en kort fengselsstraff eller ikke, må spørsmålet anses som viktig. Etter straffeprosessloven $\S 344$ skal ankedomstolen bare endre en utmålt straff dersom den finner at det er et «åpenbart misforhold» mellom den straffbare handling og straffen. Tidligere var det en diskusjon i teorien om det var et «åpenbart misforhold» når spørsmålet var om en kort fengselsstraff skulle gjøres betinget eller ubetinget, men denne oppfatningen er nå forlatt. $^{41}$

Når en dommer vurderer om straffen skal settes til en kort ubetinget fengselsstraff eller en kortere reaksjon, vil spørsmålet normalt være om det i stedet for ubetinget fengsel skal gis samfunnsstraff eller betinget fengsel, eventuelt ungdomsstraff der lovbryteren var under 18 år på gjerningstiden.

Om de forskjellige straffene kan kombineres med hverandre, avhenger av den enkelte regel. Fengsel kan gjøres delvis betinget (såkalt deldom), og kombineres med bot og med rettighetstap. Fengsel kan også kombineres med samfunnsstraff når særlige grunner tilsier det, men da kan fengselsstraffen bare være på opptil 60 dager. Samfunnsstraff kan i tillegg til fengsel kombineres med bot og rettighetstap. ${ }^{42}$ Derimot kan ungdomsstraff ikke kombineres med andre straffer. ${ }^{43}$

Bot kan kombineres med fengselsstraff, samfunnsstraff eller rettighetstap. Det gjelder selv om bot ikke er fastsatt som straff i det aktuelle straffebudet. ${ }^{44}$ Ved fastsettelse av bot skal det også fastsettes en subsidiær fengselsstraff som skal avsones hvis boten ikke betales. ${ }^{45}$ Det gjelder enten boten fastsettes i dom, forelegg eller forenklet forelegg.

\section{Lovgiverens valg i konkrete tilfeller}

Lovgiveren har altså uttalt seg prinsipielt om hensynene bak straffesystemet. Det er imidlertid et spørsmål om disse hensynene alltid ivaretas når lovgiveren skal gi enkeltregler.

\subsection{Tilståelsesrabatt}

Det har i lang tid vært et relevant moment i lovbryterens favør om han tilstår før han vet seg mistenkt. En slik tilståelse, der lovbryteren ellers kunne ha en rimelig grunn til å regne med å slippe unna, kan være et uttrykk for at han angrer og ønsker å gjøre opp for seg. Den vil også gi en etterlengtet oppklaring, og kan derfor være viktig både for den fornærmede og for folks oppfatning av at lovbrudd blir 
oppklart. Den danske dommeren von Eyben fremholdt en slik tilståelse som den eneste som burde gi et rimelig grunnlag for straffnedsettelse. ${ }^{46}$

Et straffansvar som ikke blir håndhevet, har liten effekt. Og bruker man for lang tid på sakene, går det ut over saksbehandlingstiden og den innsatsen som kan legges ned i de andre sakene. Når den mistenkte er skyldig, kan en tilståelse bidra til raskere oppklaring og en større sikkerhet for at man har fått tak i den rette gjerningspersonen. Også for den fornærmede vil det ofte være godt å få fastslått gjennom en tilståelse at den mistenkte er skyldig. På denne bakgrunn har man i Norge siden 2001 hatt en egen hjemmel til å sette ned straffen til en lavere straff eller til en mildere straffart dersom gjerningspersonen gir en uforbeholden tilståelse. ${ }^{47}$ I teori og praksis er denne ordningen omtalt som «rabatt». Normalt kan et slikt avslag i straffen bli opptil 1/3. Avslaget blir lavere jo lengre lovbryteren venter og jo sterkere bevisene allerede er mot ham.

Ordningen er beslektet med den såkalte «plea bargaining» som man kjenner blant annet fra amerikansk og engelsk rett, men med en viktig forskjell: Påtalemyndigheten kan gi den mistenkte en indikasjon på hvor stort avslaget i straffen skal være, men kan ikke binde domstolene med sin straffpåstand. ${ }^{48}$ Derimot skal domstolene opplyse i dommen om det foreligger en tilståelse som har hatt betydning for straffutmålingen, og i tilfelle bør det angis «hvilken betydning tilståelsen har hatt for straffutmålingen» ${ }^{49}$ Tanken er at det skal utvikles retningslinjer for betydningen av tilståelsen slik at påtalemyndigheten og den mistenkte har mulighet til å forutberegne konsekvensen av tilståelsen.

I forarbeidene til den opprinnelige bestemmelsen ble det kort drøftet om en tilståelsesrabatt kunne friste uskyldige til uriktige tilståelser, men avfeid med at det hørte til sjeldenhetene at folk tilstod noe de ikke hadde gjort. ${ }^{50}$ Lenge før år 2000 fantes det imidlertid internasjonal forskning som tydet på at det kunne være mer vanlig med falske tilståelser enn vi liker å tro. I dag vet vi kanskje noe mer om risikoen for falske tilståelser. Det er mange grunner til at noen vil tilstå noe de ikke har gjort: Man kan begynne å tro at man har gjort det, man kan ha psykiske problemer, man kan ønske å slippe ut av varetekt. ${ }^{51}$ Men nyere forskning kan tale for at den reduserte straff man kan oppnå ved tilståelse, også er en motiverende faktor - og viktigere enn man tidligere har forestilt seg. ${ }^{52}$

Selv om en reduksjon på inntil 1/3 ikke virker som et avgjørende argument når man ser det utenfra, kan retten også velge en mildere straffart. I noen tilfeller kan derfor den som tilstår, (håpe å) slippe ubetinget fengsel og heller få for eksempel samfunnsstraff, ungdomsstraff eller betinget fengsel. Dersom man signaliserer at en tilståelse kan føre til at lovbryteren slipper ubetinget fengsel, kan det virke svært motiverende til å tilstå. 
I norsk rett har vi i de senere år fătt mer skjematiske retningslinjer for straffutmåling i en del alvorlige saker, i en del tilfeller kombinert med høye minstestraffer. Det kan gjøre at det blir enklere for påtalemyndigheten og den mistenkte å beregne konsekvensen av en tilståelse for straffutmålingen. Det kan føre til at en tilståelse i større grad kan fremkomme etter en forhandling der påtalemyndighetens interesse i å få fortgang i saken veies mot den mistenktes vurdering av risikoen for domfellelse.

Også om den mistenkte er skyldig, kan det stilles spørsmål ved om en utstrakt bruk av en skjematisk og påregnelig tilståelsesrabatt tjener straffens formål. Sett fra påtalemyndighetens side i den enkelte sak virker ordningen åpenbart rasjonell: Kan man friste denne mistenkte til å tilstå raskt, kan denne saken oppklares og man kan konsentrere innsatsen om neste sak.

Sett fra et systemperspektiv er det ikke like opplagt at ordningen har noe for seg. Bygger man strafferetten på prevensjonsteorier, må det legges til grunn at straffenivået for en bestemt type lovbrudd må være på et visst nivå for å virke tilstrekkelig avskrekkende og skape automatisk lovlydighet og sosial ro. Kjenner potensielle gjerningspersoner til at man får en nokså skjematisk tilståelsesrabatt, vil imidlertid det opplevde straffenivået være lavere enn dette. Bygger man først og fremst på proporsjonalitet mellom handling og straff, kan det spørres om en tilståelse som utelukkende bygger på et ønske om mildere straff, gjør det rimelig å sette straffen vesentlig ned.

Det leder til et mer prinsipielt spørsmål: Det anses ikke akseptabelt å skjerpe straffen for den som ikke tilstår. Men hvis man opererer med konkrete retningslinjer for straffutmåling i en del sakstyper og skjematiske fradrag for tilståelse, kan man spørre seg om man ikke reelt sett har innført en tilleggsstraff for manglende tilståelse. Et eksempel: For lovbrudd X er det angitt et utgangspunkt om at normalstraffen skal være på tre års fengsel, men med fradrag for tilståelse på 1/3. Den som tilstår, kan altså få redusert straffen til fengsel i to år. Dersom man tenkte seg at normalstraffen skulle være på to års fengsel, men med et straffepåslag på femti prosent for den som nektet straffeskyld, ville straffen altså øke til tre års fengsel for den som nektet straffeskyld.

Uansett hvordan man konstruerer dette, vil resultatet bli at lovbryteren som tilstår, får to års fengsel; den som ikke tilstår, får tre års fengsel. Ved innføringen av regelen i straffeloven av $1902 \S 59$ annet ledd var det dissens i Stortingets justiskomité.

Flertallet i komiteen gikk inn for regelen, men understreket at datidens straffenivå ikke skulle bli mildere. Komiteens flertall forutsatte at det skulle skje en ge- 
nerell skjerping av straffenivået for bl.a. volds- og seksuallovbrudd. Mindretallet gikk derimot inn for at den som ikke tilstod, skulle få skjerpet straff. ${ }^{53}$

Mindretallets argumentasjon virker vesentlig mer drakonisk enn flertallets. Men jo mer skjematisk straffutmålingen og tilståelsesrabatten er, jo mindre blir den reelle forskjellen på de to måtene å vektlegge tilståelsen på.

Den gangen var det ikke meningen at det skulle gis konkret uttrykk i dommen for hvor mye lavere straff tilståelsen hadde ført til, men heller i mer skjønnsmessige vendinger. ${ }^{54}$ Det var heller ikke så konkret angitt hva straffen skulle være. I de senere år er dette blitt annerledes: For en del seksual- og voldslovbrudd er det angitt temmelig konkret i straffelovens forarbeider hva straffenivået skal være, og det følger som nevnt av straffeprosessloven $\S 40$ annet ledd at det skal angis konkret hvilken betydning tilståelsen har hatt for straffutmålingen. Dermed vil det $\mathrm{i}$ mange tilfeller være mulig å beregne hvor stor en tilståelsesrabatt vil bli. Det er da vanskelig å se forskjellen på en modell med «straffenivå minus tilståelsesrabatt» og «straffenivå pluss skjerpelse ved manglende tilståelse».

I tillegg kommer at en tilståelse ideelt skulle være et resultat av at gjerningspersonen ønsker å gjøre opp for seg. En slik tilståelse uten håp om konkret fordel vil antagelig være en bedre start på rehabiliteringen enn en tilståelse som kommer ut fra en kost-nytte-vurdering. Fra andre områder kjenner vi til at det å flytte en disposisjon fra det moralske til det markedsmessige univers har sine ulemper, ${ }^{55}$ og det er grunn til å spørre om ikke noe lignende kan skje når straffen blir en vare der staten kan gi en «rabatt».

Selv om man kan spare tid i den enkelte sak, er det mitt syn at en løsning der straffens lengde og art kan bli et resultat av forhandlinger, er i dårlig samsvar med strafferettens overordnede formål.

\subsection{Bøter og subsidicer fengselsstraff}

Generelt har altså lovgiveren fastsatt at straffens formål er å redusere kriminaliteten, og ramme den skyldige, ikke andre. En side av at straffen skal virke er at den blir fullbyrdet. For å skape et betalingspress mot en botlagt, har det siden eneveldets tid vært fastsatt at det ved fastsettelse av bot også skal fastsettes en subsidiær fengselsstraff som skal sones hvis boten ikke betales. ${ }^{56}$

Etter norsk rett kan man bare straffes etter dom (Grunnloven $\S 96$ første ledd), men det anses som sikker rett at man kan vedta et forelegg uten at saken har vært prøvd for retten - selv om man da altså skriver under på at man skal sone i fengsel om man ikke betaler boten. Derimot kan man ikke vedta et forelegg på betinget fengsel - det anses som for nær grunnlovsbudets kjerne. Det er altså lagt avgjørende vekt på hva som er den prinsipale straffart. - Også i straffeprosessen ser 
man langt på vei bort fra at en dom på bot innebærer en risiko for soning i fengsel. Fremmes en sak for tingretten på grunnlag av et ikke vedtatt forelegg, har man normalt ikke krav på offentlig oppnevnt forsvarer som betales av staten. ${ }^{57}$ Dersom man dømmes til bot i tingretten og påtalemyndigheten ikke har påstått noen strengere reaksjon enn bot, inndragning eller tap av førerett for motorvogn, kan anken bare fremmes om det foreligger «særlige grunner». ${ }^{58}$

Rettssamfunnets valg av straffereaksjon er prinsipielt viktig, og den botlagte har altså ikke gjort noe han skal ha fengsel for. Lovgiveren har likevel opprettholdt ordningen med subsidiær fengselsstraff. I teorien har det vært hevdet at den botlagte gjerne vil «legge ... godviljen til» for å betale boten når det trues med fengselsstraff. ${ }^{59}$ I nyere tid har det skjedd tre viktige endringer i den botlagtes favør: Siden 2012 skal det ikke lenger fastsettes noen subsidiær fengselsstraff når lovbryteren var under 18 år på gjerningstiden. ${ }^{60}$ En subsidiær fengselsstraff skal bare fullbyrdes når den botlagte har evne til å betale boten, eller allmenne hensyn taler for fullbyrding. ${ }^{61}$ Og nylig er det iverksatt en prøveordning med bøtetjeneste slik at den botlagte kan «betale» boten med arbeid. $^{62}$

Disse nye reglene endrer likevel ikke det faktum at den som ikke betaler boten, risikerer å sone i fengsel. Et særskilt problem her er at den nye ordningen med bøtetjeneste kan skape forskjeller også innad i gruppen av botlagte som ikke klarer å reise midler til å betale boten: Den som er i stand til å gjennomføre tjenesten, slipper med det; den som er for nedkjørt til å gjennomføre noen tjeneste, risikerer fengsel. Den subsidiære fengselsstraffen blir altså ikke bare et gjeldsfengsel, men et «helsefengsel» - man må til syvende og sist i fengsel fordi man ikke har krefter til å gjennomføre bøtetjeneste. Reglene vil også føre til forskjellsbehandling mellom botlagte med og uten bosted i riket. Den utenlandske botlagte som ikke har penger til boten, må i fengsel, mens den som har bosted her, får bøtetjeneste.

Når en botlagt må sone fengselsstraff fordi han ikke har skaffet midler til å betale boten, kan det sies at det strider mot proporsjonalitets- og likhetsprinsippet: Det er rettskraftig avgjort at han ikke skal sone fengselsstraff, men han må likevel sone i fengsel - i motsetning til den som har penger å betale med. En fattig lovbryter får altså strengere straff enn en mer velbemidlet lovbryter. Ordningen har vært kritisert i lang tid, men lovgiveren har valgt å opprettholde den fordi den fremmer straffens formål: Både de botlagte og allmennheten ser at bøtestraffen fullbyrdes, om enn på en mer inngripende måte enn boten ville være. Nyttehensynet går altså her foran proporsjonalitetshensynet.

Spørsmålet er imidlertid om det er «nyttig» å true botlagte lovbrytere med fengsel for å fremtvinge betaling. Det er nemlig ikke fritt fram for en botlagt bor- 
ger å velge å avsone boten i fengsel. Når et bøtekrav er rettskraftig, overtar Statens innkrevingssentral innkrevingen. ${ }^{63}$ Statens innkrevingssentral må følge prinsipper om god inkassoskikk, ${ }^{64}$ og respektere dekningslovens regler om beslagsfrihet for visse personlige midler. ${ }^{65}$ Statens innkrevingssentral kan ta utlegg i krav på lønn eller trygd, og i eiendeler skyldneren måtte ha. Staten er derfor normalt ikke avhengig av at den botlagte legger «godviljen» til; staten vil som oftest få sine penger. Det er derfor grunn til å anta at når innkrevingssentralen har gitt opp, har den botlagte vanligvis bare beslagsfrie midler igjen.

Likevel opplyste innkrevingssentralen ved høringen til ny straffelov at $77 \%$ av de botlagte som var innkalt til soning, betalte boten før den var ferdig avsonet. ${ }^{66}$ Man kan derfor spørre seg hvordan disse botlagte, som ikke har hatt noen lovlige midler innkrevingssentralen kunne ta utlegg $\mathrm{i}$, har funnet rom for å betale bøtene etter at innkallingen til soning kom.

Det kan tenkes at den botlagte har skaffet seg lovlig arbeid for å betale boten. Det kan også tenkes at den botlagte har hatt penger som han ikke har opplyst om til myndighetene, men nå bruker til å betale boten.

Det er imidlertid neppe ofte dette er måten midlene skaffes på. Det kan tenkes at den botlagte har midler som er kjent for innkrevingsmyndighetene, men som har vært beslagsfrie av hensyn til ham selv eller familiens underhold. Dersom boten betales under trussel om soning, har staten tilsynelatende gitt ham de rettigheter til å beholde midler til eget underhold som man finner passende i et sivilisert samfunn, men reelt tvunget den botlagte til å bruke midler som han og familien skulle hatt til eget underhold. Særlig der det er familiemedlemmer som må lide savn, har man fjernet seg ganske langt fra en rettferdig straff. Men også det å true med et så strengt virkemiddel at den botlagte må oppgi sitt vern etter dekningsloven, fjerner ordningen temmelig langt fra det vi vanligvis ville betegne som «god inkassoskikk».

En annen mulighet er at venner eller familie betaler boten for å unngå at den botlagte må sone i fengsel. Dette skaper et tap eller en betydelig kredittrisiko for den som betaler boten for den botlagte, og er vanskelig å forene med at straffen skal ramme den skyldige. Fortsatt kan man kanskje likevel si at ordningen er «nyttig» ved at straffen fullbyrdes, selv om fullbyrdingen er nokså hard mot den botlagtes nærstående.

Det er imidlertid neppe helt uvanlig at den botlagte skaffer seg penger på måter som direkte strider mot straffens formål. Dersom den botlagte prostituerer seg for å penger til å betale boten, blir kunden skyldig i seksuallovbrudd. ${ }^{67} \mathrm{Og}$ også i land som ikke har straffbelagt det å kjøpe seksuelle tjenester, oppfattes prostitusjon normalt som lite ønskelig. 
Dersom den botlagte tar «svart arbeid» for å betale boten, begår han en ny straffbar handling. ${ }^{68}$ Det samme gjelder dersom han skaffer penger ved vinningseller narkotikakriminalitet.

Til tross for at reglene om subsidiær fengselsstraff for bøtekrav har vært endret to ganger i de senere år, er det ikke foretatt noen slik analyse av hvor de botlagte som betaler nærmest i porten til fengselet, egentlig har fått sine penger fra. Det er grunn til å spørre om ordningen rammer andre enn den skyldige, og om den hemmer eller fremmer kriminalitet.

\subsection{Beregningen av de administrative og økonomiske konsekvensene av betydelige straffskjerpinger}

Når nye regler forberedes, er det en del av arbeidet å vurdere de administrative og økonomiske konsekvenser for både det offentlige og private.

Som det fremgår innledningsvis, bygger norsk strafferett prinsipielt på prevensjonsteorier: Gjengjeldelse er ikke straffens formål. Når man går inn for å øke straffenivået dramatisk, ville det derfor være rimelig å anta at analysen av de administrative og økonomiske konsekvenser inneholdt en drøftelse av om den brutto økningen i straffenes lengde kunne kompenseres noe av at den aktuelle kriminaliteten gikk ned.

I 2010, i forbindelse med vedtagelsen av straffeloven av 2005, fikk vi i Norge en økning i straffenivået for flere typer lovbrudd. I lovforarbeidene gikk departementet lengre enn tidligere med å angi et normalstraffenivå. Minstestraffen for voldtekt til samleie og for samleie med barn under 14 år ble økt fra to til tre år, og det ble i forarbeidene angitt en normalstraff på fengsel i fire år. For samleie med barn over 14, men under 16 år, hadde normalstraffenivået tidligere vært 60 dager når barnet var under 15 år. ${ }^{69}$ Nå ble normalstraffenivået angitt til ubetinget fengsel i seks måneder ved samleie, også når barnet er fylt 15 år. $^{70}$ For voldslovbrudd (kroppskrenkelse ${ }^{71}$ med uforsettlig skadefølge) ble normalnivået angitt å skulle øke fra 30-45 dager ubetinget fengsel til «ikke ... under 60 dager fengsel». For kroppskrenkelse som var på grensen til kroppsskade, ble normalnivået angitt å skulle økes fra «opp mot 75 dager» til «ikke ... under 90 dager ubetinget fengsel». ${ }^{72}$

Ved vurderingen av de administrative og økonomiske konsekvensene ved straffskjerpingene beregnet Justisdepartementet i utgangspunktet behovet til 50100 soningsplasser, men anslo at økt bruk av samfunnsstraff på andre områder ville veie opp for behovet for økte fengselsplasser. Det ble ikke fremlagt tall som støttet teorien om at antallet samfunnsstraffdommer på andre områder ville øke så 
meget. Om dette var en riktig prognose, skal være usagt - i 2015 begynte Norge for første gang å leie fengselsplasser i utlandet for å forkorte soningskøen.

Det er nok så at det ville være overraskende om det var mulig å dokumentere at en kraftig straffskjerping ville få vesentlig betydningen for kriminaliteten på et område. Det er naturlig å forstå forarbeidenes taushet som at dette heller ikke var intensjonen. De kraftige straffskjerpelsene var heller et eksempel på signallovgivning. $^{73}$

Vel så interessant som hva som ble vurdert, er hva som ikke ble det.

Etter de alminnelige retningslinjene for vurdering av administrative og økonomiske konsekvenser skal også konsekvensene for private vurderes. For den enkelte domfelte og de pårørende kan det være temmelig inngripende at straffenivået øker. Det gjelder ikke minst hvis det alminnelige straffenivået for en type lovbrudd øker så meget at det får betydning for den domfeltes arbeidsforhold.

At en arbeidstager blir dømt for en straffbar handling, kan i seg selv gi arbeidsgiveren grunnlag for å si opp eller avskjedige vedkommende. Men er forholdet ikke av en slik karakter at det i seg selv gir arbeidsgiveren rett til avskjed eller oppsigelse, kan det bli avgjørende hvor langt fravær arbeidstageren făr etter soning. Høyesterett har i enkelte avgjørelser tatt hensyn til den domfeltes arbeidsforhold ved reaksjonsvalget. ${ }^{74}$ Etter norsk rett må det legges til grunn at arbeidstageren har risikoen for fravær på grunn av soning, men at forholdsvis kortvarige fravær ikke uten videre gir arbeidsgiveren grunnlag for å si opp arbeidstageren. ${ }^{75}$ Det kan derfor være avgjørende om straffenivået går opp fra 30-60 dager til seks måneder.

Generelt er det et uttalt mål i norsk kriminalpolitikk at straffede skal resosialiseres, og at et viktig moment ved resosialiseringen er at den domfelte skal ha et arbeidsforhold å gå til ved løslatelse etter endt soning. Stortinget kan selvsagt velge å skjerpe straffenivået likevel, men det kan spørres om de arbeidsrettslige konsekvensene av straffskjerpingene ikke burde vært presentert for Stortinget.

\section{Rettspraksis: Har det teoretiske utgangspunktet betydning for valget av reaksjon?}

Et strafferettssystem må håndheves. De fleste straffebud har fengsel som ett av straffalternativene, men spørsmålet er hvor domstolene i praksis trekker grensen mellom ubetinget fengsel og mildere reaksjoner.

Fram til 1995 var Høyesterett den ordinære ankeinstans over dommer fra herreds- eller byretten (som nå heter tingrett), og behandlet derfor svært mange straffesaker. ${ }^{76}$ Etter to-instansreformen er lagmannsretten ankeinstans for tingrettens avgjørelser, og Høyesteretts hovedoppgave er nå rettsavklaring og rettsutvikling. 
Fortsatt har likevel Norges Høyesterett en sentral stilling i normeringen av straffutmålingen. ${ }^{77}$

Man kan se på Høyesteretts dommer som en form for institusjonalisert historiefortelling: De fleste straffebud har forholdsvis vide strafferammer, og de formildende og skjerpende omstendighetene er bredt angitt i loven, uten noen nærmere prioritering mellom dem. Leter man etter den faktiske straff som kan være aktuell dersom noen uaktsomt forvolder en annens død, angir loven at straffen er «fengsel inntil 6 år». ${ }^{78}$ Men som det fremgår av punkt 1.5 ovenfor, suppleres lovbudenes strafferammer av reglene i lovens alminnelige del. I prinsippet kan reaksjonen bli straffutmålingsfrafall, ${ }^{79}$ betinget fengsel, samfunnsstraff eller ungdomsstraff i stedet for fengsel. Skal man finne ut hva som er den aktuelle straffen for et konkret tilfelle, må man ty til rettspraksis.

Litt forenklet kan man dele straffebudene inn i tre: I den minst alvorlige gruppen blir det så å si aldri gitt fengsel selv om strafferammen tillater det. I den mest alvorlige gruppen er det nærmest utelukket å gi noe annet enn ubetinget fengsel (eller forvaring). Mitt tema er den midtre gruppen, der det etter rettspraksis kan gis enten ubetinget fengsel eller mildere reaksjoner.

\subsection{Utgangspunktet: Den straffbare handling}

Utgangspunktet for straffutmålingen i en konkret sak er selvsagt den straffbare handling og gjerningspersonens utviste skyld. Dette utgangspunktet er det samme uansett straffeteori: Bygger man primært på gjengjeldelse og proporsjonalitet, er det selvsagt handlingen som må bedømmes. Men det må det også være når man bygger på prevensjonsteoriene. Jo farligere en handling er, og jo større gjerningspersonens skyld er, jo viktigere vil det være å avverge denne typen kriminalitet og å gi folk trygghet for at strafferetten håndheves.

Dette er likevel bare et utgangspunkt. Når prevensjonsteoriene trekkes inn i bedømmelsen av enkeltsaker, kan det føre til at man legger mindre vekt på proporsjonalitet og likhet.

Et eksempel er at straffenivået skjerpes på grunn av kriminalitetsutviklingen. I utgangspunktet kan ikke gjerningspersonen lastes for hva andre har gjort. Etter en ren proporsjonalitetsteori vil det derfor normalt ikke være akseptabelt å skjerpe straffen fordi det er en økning i den aktuelle typen kriminalitet. Bygger man på prevensjonsteorier, kan det falle lettere: En økning i antallet trafikkulykker kan være et argument mot milde straffer for trafikklovbrudd. En økning i antallet ran eller tyverier på offentlig sted kan være et argument for å øke straffen.

I en mellomstilling kommer sakstyper der man etter hvert er blitt klar over at skadevirkningene er større enn man tidligere trodde. Det klassiske eksempelet er 
seksuallovbrudd mot barn, der straffenivået er vesentlig skjerpet i løpet av et par tiår. Denne skjerpingen er begrunnet $i$ at det viser seg at barn kan få langt mer alvorlige langtidsskader av å bli utsatt for seksuallovbrudd enn det man trodde tidligere. Her er det i og for seg hensynet til proporsjonalitet som kommer inn: Skal man gjengjelde den skaden som er gjort, vil en økt oppmerksomhet om skadene tale for en strengere reaksjon. I de prinsippavgjørelsene vi har om slik straffskjerping, er det imidlertid ikke drøftet om det har betydning hva gjerningspersonen visste om langtidsvirkningene.

Det er et ideal for strafferetten at den skal ta hensyn til den alminnelige rettsfølelse. ${ }^{80}$ Samtidig vil strafferetten også i noen grad påvirke rettsfølelsen. Når man bygger på prevensjonsteorier, kan man få den situasjon at dommeren velger en streng reaksjon fordi mange ikke tar straffetrusselen tilstrekkelig alvorlig. Et eksempel er saker om trygdebedrageri, der Høyesterett i en sak har fremholdt at mange nok vegrer seg mindre for å bedra trygdemyndighetene enn for å bedra en privatperson - og at man derfor må velge en streng straff for å styre atferden. ${ }^{81}$

Når straffutmålingen styres av proporsjonalitet, vil man behandle like tilfeller likt. Det må også være et mål når utmålingen styres av prevensjonshensyn. Men forskjellen i utgangspunkt kan påvirke hva som er «likt». Et eksempel kan være straffutmålingen ved forsikringsbedragerier ${ }^{82}$ sammenlignet med trygdebedragerier.

Etter straffeloven av $1902 \S 272$ var lovens system annerledes enn nå: Det å fremkalle et forsikringstilfelle eller oppgi til erstatning en gjenstand som ikke var til eller ikke var skadet, kunne straffes med fengsel i inntil seks år. Denne strafferammen tilsvarte strafferammen for grovt bedrageri (straffeloven av 1902 § 271). Strafferammen var derimot bøter eller fengsel i inntil tre år for den som fortiet relevante opplysninger ved inngåelsen av forsikringsavtalen, eller for å få en forsikringssum som stod i et påtakelig misforhold til skaden. - Høyesterett har ved straffutmålingen lagt en viss vekt på hvilket alternativ i straffebudet som var overtrådt, men har ikke latt det få avgjørende betydning for valget mellom ubetinget fengsel og mildere reaksjoner. ${ }^{83}$

Før 1990-tallet ble disse to lovbruddstypene stort sett straffet nokså likt; utgangspunktet var ubetinget fengsel selv ved små beløp. ${ }^{84}$ Det kan ha gode grunner for seg i begge tilfeller: Både trygd og forsikring er preget av at de fleste samfunnsborgere betaler inn bidrag til en felleskasse og får igjen penger når bestemte hendelser inntrer. Det kan skade ordningenes legitimitet når noen får penger de ikke har krav på.

Ved inngangen til 1990-tallet endret dette seg for trygdebedrageri: Etter hvert la Høyesterett til grunn at det var akseptabelt å dømme til betinget fengsel inntil rundt 20000 kroner. ${ }^{85}$ På 2000-tallet ble grensen ytterligere justert: I 2002 ga 
Høyesteretts flertall samfunnstjeneste for et trygdebedrageri på kr $53306 .{ }^{86}$ Etter hvert ble utgangspunktet tatt i folketrygdens grunnbeløp på gjerningstiden. ${ }^{87}$

Folketrygdens grunnbeløp er fastsatt i folketrygdloven $\S 1-4$ og justeres årlig i takt med lønnsveksten. Per 1. mai 2015 var grunnbeløpet kr 90 068. Side grunnbeløpet er en beregningsfaktor som har betydning for retten til ytelser og for størrelsen på ytelser etter folketrygdloven, har Нøyesterett lagt til grunn at utviklingen i grunnbeløpet gir en god indikator for hvor alvorlig et trygdebedrageri er. Grunnbeløpet vil gjennomgående øke mer enn konsumprisindeksen. Fra 1. mai 1998 til 1. mai 2015 ble grunnbeløpet om lag doblet (fra kr 45370 til kr 90 068). Prisstigningen var på 40 \%. Et beløp på kr 45370 i mai 1998 tilsvarer kr 63 527,10 i mai 2015. Det er ikke avklart i Høyesteretts praksis om grensen nedad mellom samfunnsstraff og betinget fengsel skal trekkes med utgangspunkt i konsumprisindeksen eller grunnbeløpet. ${ }^{88}$

Som det fremgår av innledningen, er allmennprevensjonen ansett som styrende også i enkeltsaker. Avveiningen vil likevel bli annerledes enn når lovgiveren vurderer om noe skal kriminaliseres. For dommeren i den enkelte sak vil også utgangspunktet avhenge av om det finnes sammenlignbar praksis. Men i spørsmålet om hva som er sammenlignbar praksis, kan hensynet til allmennprevensjonen få betydning. Et eksempel er igjen forholdet mellom trygdebedrageri og forsikringsbedrageri. Det er vanskelig å se det annerledes enn at hensynet til proporsjonalitet taler for en lik behandling av de to lovbruddstypene. Høyesterett har imidlertid altså lagt til grunn at hensynet til allmennprevensjonen taler for en vesentlig lavere grense for ubetinget fengsel ved forsikringsbedragerier enn ved trygdebedragerier. ${ }^{89}$ Begrunnelsen var at den som leverer et uriktig krav på en forsikringsytelse kan beregne størrelsen på kravet selv, slik at det ikke bør være for faste grenser for bruk av ubetinget fengsel. Ellers ville den potensielle gjerningspersonen kunne kreve et beløp som var under grensen for ubetinget fengsel. Нøyesteretts flertall var altså her opptatt av allmennprevensjonens avskrekkende funksjon.

\subsection{Prosess: Betydningen av meddommernes vota}

I norsk straffeprosess brukes meddommere i stor utstrekning i tingretten og i de mest alvorlige sakene i lagmannsretten. Også ved anker over straffutmålingen i lagmannsretten brukes meddommerne i disse alvorlige sakene. Begrunnelsen er blant annet at meddommerne kan gi fagdommerne informasjon om hva «den alminnelige rettsfølelse» tilsier om reaksjonsvalget.

«Den alminnelige rettsfølelse» kan ha betydning både når lovgiveren vurderer kriminalisering og strafferammer, og ved vurdering i enkeltsaker. Begrepet er nært beslektet med «den sosiale ro», som i forarbeidene til straffeloven av 2005 
er omtalt som en del av allmennprevensjonen. Det kan imidlertid spørres om rettsfølelsen egentlig er så felles. ${ }^{90}$ Det er også godt dokumentert at folk svarer forskjellig når de blir spurt generelt om straffenivået, og når de blir presentert for konkrete saker med opplysninger om gjerningspersonens personlige forhold. ${ }^{91}$

I den grad man bør legge vekt på allmennhetens rettsfølelse, kan det argumenteres for at meddommerne i de underordnede instanser gir det beste uttrykket for hva den er. ${ }^{92}$ Riktig nok er de få i den enkelte sak, men de kjenner saken godt, har fulgt forhandlingene i retten, kan diskutere seg imellom og må trekke sine konklusjoner under dommeransvar.

Det rokker ikke ved at Høyesterett dømmer i siste instans, og har et selvstendig ansvar for rettsavklaring og rettsutvikling. ${ }^{93}$ Men det å bruke meddommere ved straffutmålingen krever ressurser for det offentlige og legger beslag på borgeres tid. I lys av forarbeidenes vektlegging av meddommernes kunnskap om den alminnelige rettsfølelse skulle man derfor tro at Høyesterett i tvilstilfelle ville legge vekt på meddommernes syn.

Når det er dissens i Høyesterett om straffutmålingen, må det legges til grunn at spørsmålet om reaksjonsvalg er skjønnsmessig og begge løsninger kan forsvares innenfor rammen av relevante straffutmålingsmomenter. Normalt vil en av fraksjonene stemme for å opprettholde underinstansens dom eller fastsette en straff i nærheten av dette. I slike tilfeller hender det at den fraksjonen som stemmer for å opprettholde underinstansens dom, viser til at underinstansen har sett den tiltalte og er kommet fram til sitt resultat gjennom umiddelbar bevisføring. Til tross for at forarbeidene begrunner bruken av meddommere i straffutmålingsanker med hensynet til den alminnelige rettsfølelse, er det heller sjelden at Høyesterett viser til hva meddommerne har stemt - selv når retten viser til den alminnelige rettsfølelse. Etter hva jeg har funnet i saker der Høyesterett viser til den alminnelige rettsfølelse ved straffutmåling, er det bare én gang meddommernes vota trekkes inn i begrunnelsen:

I Rt. 1962 s. 588 hadde herredsrettens flertall - meddommerne - gitt ubetinget fengsel for legemsfornærmelse med skadefølge, ${ }^{94}$ mens fagdommeren hadde stemt for betinget fengsel. I Høyesterett ble straffen under dissens 3-2 satt til betinget fengsel i seks måneder på vilkår av at den domfelte avholdt seg fra alkohol og betalte erstatning til den fornærmede. Mindretallet stemte for å opprettholde byrettens straffutmåling og fremholdt:

«Sist, men ikke minst, skal jeg fremheve at det etter mitt syn vil være i strid med den alminnelige rettsfølelse om en forbrytelse som denne praktisk sett forblir ustraffet. Jeg ser en bekreftelse på dette i de to domsmenns reaksjon, som jeg forstår og billiger.» 
I saker der Høyesterett har vist til «den alminnelige rettsfølelse» eller lignende, har det vært noe varierende om retten var strengere eller mildere. Men et særpreg er at retten - bortsett fra i dommen fra 1962 - stort sett har drøftet betydningen av den alminnelige rettsfølelse uten å nevne hva meddommerne i de underliggende instansene er kommet til. ${ }^{95}$

I Norge har vi i de senere år fått betydelige straffskjerpinger, dels ved at minstestraffene for en del lovbrudd er økt, og dels ved at lovgiveren har gitt detaljerte anvisninger om straffenivået. I en del tilfeller har man gått gjennom konkrete høyesterettsdommer og angitt hva som nå skal være det riktige nivået. Det er på det rene at Høyesterett i en del saker har opprettholdt milde avgjørelser av underrettene. I en sak om seksuelt overgrep mot barn, der flertallet i Høyesterett opprettholdt lagmannsrettens utmåling av samfunnsstraff mot en 17 år gammel gutt, argumenterte flertallet med lagmannsrettens bevisvurdering, men ikke med at legdommerne i lagmannsretten hadde gått inn for samfunnsstraff. Derimot argumenterte mindretallet - som ville skjerpe straffen - med den alminnelige rettsoppfatning. ${ }^{96}$

Hadde Høyesterett i dommene der retten ga strengere eller like strenge straffer som meddommerne passet på å understreke dette poenget, kunne det vært vanskeligere politisk å hevde at Høyesteretts praksis var for mild. I hvert fall måtte man da argumentert for at meddommernes rettsoppfatning systematisk var lite representativ for hva folk ellers mente.

\section{Konsekvenser av reaksjonsvalget}

I norsk rett har vi flere regler som knytter sivilrettslige følger ikke bare til om man er straffet, men til hvilken reaksjon som ble ilagt. Siden denne artikkelen retter seg mot et nordisk publikum, skal jeg her være kort. Siden en lignende analyse ikke er gjort i norsk strafferett tidligere, tillater jeg meg å nevne noen hovedpunkter.

De hensyn som er relevante ved straffutmåling, dreier seg ikke bare om handlingens karakter og gjerningspersonens skyld, men også om en rekke andre forhold: Tiden fra lovbruddet til pådømmelsen, gjerningspersonens ansvar for barn, hensynet til rehabilitering osv. To gjerningspersoner som har utøvd lignende handlinger og utvist den samme skyld, kan dermed få nokså forskjellige reaksjoner. Det kommer man ikke utenom i en human strafferettspleie. Det er ikke alltid rettferdig å være like streng mot alle.

Reglene om de sivilrettslige konsekvensene av straffereaksjoner knytter seg derimot i flere tilfeller til arten og lengden av den utmålte reaksjonen. To lovbry- 
tere som får forskjellig straff på grunn av personlige forhold mm. hos den ene, vil dermed også få forskjellige sivilrettslige følger av lovbruddet.

Arten og lengden av den strafferettslige reaksjonen har betydning for hvor lenge en straffereaksjon står på en ordinær politiattest, noe som kan få betydning for adgang til en del studier og yrker. Det kan dels fremstå som urettferdig, og dels gi en falsk trygghet for den som stoler på attesten. ${ }^{97}$

Etter norsk rett har reaksjonsformen også betydning for om man skal miste arveretten etter lovbrudd. Er et barn unnfanget etter bestemte typer seksuallovbrudd fra farens side, tar ikke farsslekten arv etter barnet - men bare hvis faren er dømt til ubetinget fengsel. Det vil si at en utilregnelig gjerningsmann ikke vil miste arveretten. ${ }^{98}$ Det vil også si at en gjerningsmann som får samfunnsstraff eller ungdomsstraff på grunn av lav alder, tar arv. Hvor praktisk viktig regelen er, kan diskuteres - men regelen er foreslått videreført i Arvelovutvalgets utkast til ny arvelov, og gjort kjønnsnøytral. ${ }^{99}$

Mer praktisk er nok regelen om at en arving kan fradømmes arveretten hvis han eller hun har begått et lovbrudd som fører til arvelaterens død. ${ }^{100}$ Også her kreves det etter norsk rett at arvingen idømmes ubetinget fengsel. At en utilregnelig arving beholder arveretten her, er kanskje ikke så urimelig - men regelen hindrer også tap av arverett dersom straffen blir for eksempel samfunnsstraff eller ungdomsstraff på grunn av arvingens personlige forhold. - En tilsvarende regel om tap av rett til forsikringsytelser er også knyttet til om gjerningspersonen ble idømt ubetinget fengsel. ${ }^{101}$

Selv om det i utgangspunktet er en sammenheng mellom det straffbare forholdets karakter og alvor og straffereaksjonen, er unntakene fra dette utgangspunktet mange. Det kan diskuteres om ikke sivilrettslige følger av straffbare handlinger burde reguleres på en annen måte, for eksempel ved en henvisning til det straffbare forholdets karakter, eller strafferammen.

\section{Oppsummering}

Prevensjonsteoriene er tilsynelatende humane: Straff brukes som et middel til å oppnå et gode som presumptivt er større enn det ondet man påfører lovbryteren. Men prevensjonsteoriene kan tilsløre realiteten: Straff fremstår som formålsrasjonalitet mer enn som et moralsk valg. En lovgiver som skjerper strafferammen, eller en dommer som skjerper straffen, kan henvise til «allmennprevensjonen» og fremstå nærmest som en ingeniør som forutsier en virkning, men treffer i realiteten moralske valg om hvor mye et annet menneske skal tåle av straff. Det er en viktig og nødvendig oppgave, men verdivalgene bør ikke tilsløres. 
Et viktig formål med straffen er kommunikasjon, og det kan bedre denne kommunikasjonen om vi erkjenner at utmåling av straff ikke dreier seg om å forutsi en virkning, men om å treffe et verdivalg.

\section{Noter}

1. Cand.jur., Universitetet i Oslo 1989. Han forsvarte sin ph.d.-avhandling ved samme universitet i februar 2016. Tidligere bl.a. førstestatsadvokat ved Riksadvokatembetet, kontorsjef hos Sivilombudsmannen og lovrådgiver i Justisdepartementet, Lovavdelingen.

2. Andenæs (1962, s. 135), Nelson (1990, s. 73).

3. Jareborg og Zila (2010).

4. Statistisk Sentralbyrå (2015), lesedato 29. februar 2016. Se også avhandlingen s. 13.

5. Holmboe (2016a). Takk til bedømmelseskomiteens medlemmer (professor (em.) Jon T. Johnsen, professor Thomas Elholm og høyesterettsdommer (em.) Kirsti Coward) for konstruktive kommentarer. - En noe revidert versjon av avhandlingen er under utgivelse på Gyldendal Norsk Forlag.

6. Hauge (2002).

7. St.meld. nr. 104 (1977-78).

8. Høgetveit (2002), Heffermehl (2002), Andenæs (2002). En oversikt over utredningene er gitt i Ot.prp. nr. 90 (2003-2004). Se også Myhrer (2008).

9. Ot.prp. nr. 90 (2003-2004), Ot.prp. nr. 8 (2007-2008), Ot.prp. nr. 22 (2008-2009). Den første proposisjonen (Ot.prp. nr. 90 (2003-2004)) behandlet lovens alminnelige del og en del prinsipielle spørsmål om kriminalisering. Se nærmere Myhrer (2008).

10. Se lov 19. juni 2015 nr. 65 og Prop. 64 L (2014-2015). - For en grundig behandling av den nye straffeloven, se Matningsdal (2010), Matningsdal (2015b), Matningsdal (2015c). Mange grunnleggende spørsmål om straffens begrunnelse er drøftet i Gröning m.fl. (2015).

11. Holmboe (2016a, s. 47-50).

12. Ot.prp. nr. 90 (2003-2004) (s. 77-80).

13. Innst. O. nr. 72 (2004-2005) (s. 25).

14. Kinander (2013), Nymo (2015).

15. Jf. for eksempel Boucht og Frände (2007, s. 235-240), Asp og Ulväng (2014, s. 66-68).

16. Rawls (1955).

17. Ross (1969), Andenæs (1971), Ross (1971).

18. Evald (2010), Blume (2011), Bjarup (2014). Se også Jareborg (2006).

19. $\operatorname{Elholm}(2010$, s. 25).

20. Ot.prp. nr. 90 (2003-2004) (s. 77).

21. Rui (2014).

22. Coward (2015, s. 83).

23. Se for eksempel Rt. 2003 s. 1464 (forsikringsbedrageri), som er nærmere behandlet nedenfor.

24. Myhrer (2011, s. 91).

25. Ot.prp. nr. 90 (2003-2004) (s. 80).

26. Jareborg (1992, s. 138-139).

27. Jf. nærmere under punkt 3.2 nedenfor. 
28. Coward (2015, s. 83).

29. Straffeloven av $1902 \S 257$; se nå straffeloven av $2005 \S 321$.

30. Andenæs (1996, s. 123), Andenæs (1997, s. 16). Se også Andenæs (2004, s. 475).

31. Se for eksempel Rt. 2003 s. 208 og Rt. 2003 s. 907.

32. Myhrer (2011, s. 88-89).

33. For en oversikt over restorative justice, se for eksempel Zehr (2008), Johnstone (2011), Gröning og Jacobsen (2012), Lie (2015), Cornwell m.fl. (2013). For innlegg både for og mot restorative justice, se Cunneen og Hoyle (2010). En kritisk gjennomgang av de norske «stormøtene» i regi av konfliktrådene er gitt av Asmussen (2014), Asmussen (2015).

34. Se lov 20. juni $2014 \mathrm{nr}$. 49, som erstattet den tidligere loven av 15. mars $1991 \mathrm{nr}$. 3. Om konfliktrådsloven av 2014, se Prop. 57 L (2013-2014), Holmboe (2016c).

35. Christie (1977a), Christie (1977b). Et sammendrag av artikkelen er tatt med i et utvalg av grunnleggende tekster om restorative justice forholdsvis nylig, og artikkelen er analysert i en nyere bok om grunnleggende tekster i strafferetten. Se Christie (2013), Halvorsen (2014).

36. Holmboe (2016a, s. 40-43).

37. Se konfliktrådsloven av 2014 kapittel IV. Reglene i straffeloven og konfliktrådsloven om ungdomsstraff er kommentert av Matningsdal (2015c, s. 485-527). Kritiske spørsmål om ungdomsstraff er blant annet fremsatt i Iversen (2013a), Iversen (2013b), Christie (2015), Scherger (2015), Holmboe (2016b), Holmboe (2014).

38. Bestemmelsen er nærmere kommentert av Matningsdal (2015c, s. 271-273). De strafferettslige reaksjonene er listet opp i straffeloven $\S 30$.

39. Holmboe (2004a), Holmboe (2004b).

40. Straffeloven $\S 31$ annet ledd.

41. Andenæs (1984).

42. Straffeloven $\S 32$ og $\S 51$.

43. Se straffeloven $\S 52$ a, jf. Prop. 135 L (2010-2011) (s. 166-167). Dette kan slå uheldig ut der lovbryteren etter attenårsdagen begår nye lovbrudd som skal pådømmes samtidig med et lovbrudd som kunne gitt ungdomsstraff; se Holmboe (2014, s. 401-402).

44. Straffeloven $\S 54$.

45. Straffeloven $\S 55$.

46. Eyben (1950, s. 232).

47. Straffeloven av $2005 \S 78$ bokstav f og $\S 80$ bokstav a nr. 2. (Jf. tidligere straffeloven av $1902 \S 59$ annet ledd, som ble tilføyd ved lov 2. mars $2001 \mathrm{nr}$. 7.).

48. Rt. 2009 s. 1336.

49. Straffeprosessloven $\S 40$ annet ledd.

50. Ot.prp. nr. 81 (1999-2000) (s. 33).

51. Se Stridbeck (2015).

52. Dervan og Edkins (2013). Om betydningen av differansen mellom straffen med og uten tilståelse, se også Langbein (1978, s. 12), Christie (1993).

53. Innst. O. nr. 45 (2000-2001) (s. 8). Mindretallet var representantene fra Fremskrittspartiet, som den gang var i opposisjon, men som siden 2013 har sittet i regjering og (per april 2016) har justisministeren.

54. Ot.prp. nr. 81 (1999-2000) (s. 55).

55. Bowles og Polania-Reyes (2012). 
56. Se Norske Lov 1-22-11: «Ved Bøder paa Sølv forstaais saa mange Penge i Mynt, som Sølvet er værdt; Haver mand ikke Formue at bøde med, da straffis paa Kroppen.» Jf. Midbøe (1960, s. 4).

57. Straffeprosessloven $\S 96$ første ledd nr. 2.

58. Straffeprosessloven $\S 321$ første ledd.

59. Andenæs (2004, s. 427).

60. Straffeloven $\S 55$ siste ledd.

61. Straffeprosessloven $\S 456$.

62. Straffegjennomføringsloven $\S 16$ a.

63. Straffeprosessloven $\S 456$.

64. Lov om statens innkrevingssentral (SI-loven) $\S 3$.

65. Dekningslovens kapittel 2.

66. Ot.prp. nr. 90 (2003-2004) (s. 312).

67. Straffeloven $\S 316$.

68. Straffeloven $\S 378$.

69. Se for eksempel Rt. 2010 s. 36 og Rt. 2010 s. 1421.

70. Prop. 97 L (2009-2010) (s. 27).

71. Straffeloven av $2005 \S 271$ og $\S 272$. «Kroppskrenkelse» ble tidligere kalt «legemsfornærmelse» (straffeloven av $1902 \S 228$ ). «Kroppsskade» (straffeloven av $2005 \S 273$ og $\S 274$ ) ble tidligere kalt «legemsbeskadigelse» (straffeloven av 1902 § 229).

72. Prop. 97 L (2009-2010) (s. 33).

73. Se generelt Elholm (2011).

74. Se for eksempel Rt. 2012 s. 1089; Rt. 2013 s. 978 (mindretallets votum, avsnitt 30); Rt. 2014 s. 459.

75. Rt. 1992 s. 1482, der et fravær på to måneder og 19 dager utover det arbeidstageren hadde krav på som ferie og avspasering, ga grunnlag for oppsigelse. Men Høyesterett fremholdt at kortere fravær ikke uten videre ville gi rett til oppsigelse. Se også Rt. 2011 s. 74, der fravær på grunn av varetektsfengsling i fire uker ikke ga grunnlag for oppsigelse. Avgjørelsene er kommentert av Fougner (2011).

76. For en oversikt over rettsstillingen før to-instansreformen, se NOU 1992: 28 (s. 35 flg.), Andenæs (1984), Backer (1990). Om ordningen etter reformen, se for eksempel Husabø (1994), Matningsdal (1996), Matningsdal (2006).

77. Jf. for eksempel Matningsdal (2015a).

78. Straffeloven $\S 281$. Jf. tidligere straffeloven av $1902 \S 239$.

79. Reaksjonsformen straffutmålingsfrafall er ny med straffeloven av 2005, og særlig tiltenkt lovbrytere som uaktsomt har forvoldt nærståendes død. Tanken er at man i et slikt tilfelle har lidd nok om man ikke skulle måtte sone straff også. Et eksempel på at hensynene bak regelen fikk betydning for straffutmålingen også før straffeloven av 2005 trådte i kraft, er Borgarting lagmannsretts dom av 1. juli 2015 (LB-2015-18247). Om ordningen, se Lånke (2008), Holmboe (2011), Matningsdal (2015c, s. 578-581).

80. Jf. Frøseth m.fl. (2016).

81. Rt. 2014 s. 691 avsnitt 23.

82. Straffeloven $\S 375 \mathrm{og} \S 376$ (vanlig og grovt forsikringsbedrageri).

83. Rt. 2005 s. 926. 
84. Se for eksempel Rt. 1983 s. 299 (trygdebedrageri på kr 1995 ga ubetinget fengsel). Dommen er kritisert av Andenæs (1984). Ubetinget fengsel var utgangspunktet også ved forsikringsbedragerier, men det fantes unntak ved små beløp. For eksempel dømte Høyesterett en 21 år gammel mann til betinget fengsel for forsikringsbedrageri av kr 2625 i Rt. $1985 \mathrm{~s}$. 71.

85. Rt. 1991 s. 1026 , Rt. 1991 s. 1028 og Rt. 1991 s. 1066 (398-91).

86. Rt. 2002 s. 1403.

87. Rt. 2008 s. 1386.

88. Se nærmere avhandlingen s. 152-154.

89. Rt. 2003 s. 1464.

90. Jerre (2013a), Jerre (2013b).

91. Litteraturen er omfattende. Her nøyer jeg meg med å nevne Balvig m.fl. (2010), Stridbeck (2010), Balvig m.fl. (2011), Olaussen (2011), Olaussen (2013), Ryberg og Roberts (2014), Frøseth m.fl. (2016).

92. Jf. Warner og Davis (2012).

93. Grunnloven $\S 88$ og $\S 90$.

94. Straffeloven av $1902 \S 228$ første og annet ledd. Se nå straffeloven av $2005 \S 271$ og $§ 272$ om kroppskrenkelse.

95. Se for eksempel Rt. 2004 s. 610.

96. Rt. 2004 s. 327.

97. Holmboe (2016a, s. 247-268).

98. Arveloven $\S 4$ annet ledd. Jf. avhandlingen s. 273-279.

99. NOU 2014: 1 (s. 28-29).

100. Arveloven $\S 73$. Jf. avhandlingen s. 279-283. For en oversikt over nordisk rett, se Danielsen (1994).

101. Forsikringsavtaleloven $\S 15-9$. Jf. avhandlingen s. 283-284.

\section{Referanser}

\section{Litteratur}

Andenæs, J. (1962). Straffutmåling Avhandlinger og foredrag (s. 133-147). Oslo: Universitetsforlaget.

Andenæs, J. (1971). «Straffens formål.» Et tilsvar til professor Alf Ross. Tidsskrift for Rettsvitenskap, 84(2), 151-155.

Andenæs, J. (1984). Høyesterett som ankeinstans for straffutmålingen. I H.M. Michelsen, H. Røstad \& G. Aasland (Red.), Rett og rettssal: et festskrift til Rolv Ryssdal (s. 261-279). Oslo: Aschehoug.

Andenæs, J. (1996). Straffen som problem. Halden: Exil.

Andenæs, J. (1997). Prevensjon og rettferdighet i straffutmåling. I V. Hagstrøm, P. Lødrup \& M. Aarbakke (Red.), And og rett. Festskrift til Birger Stuevold Lassen på 70-årsdagen 19. august 1997 (s. 11-21). Oslo: Universitetsforlaget.

Andenæs, J. (2002). Straffelovkommisjonens innstilling om ny straffelov. Tidsskrift for Strafferett, 2(2), 162-167.

Andenæs, J. (2004). Alminnelig strafferett. Ved Magnus Matningsdal og Georg Fredrik RieberMohn (5. utg.). Oslo: Universitetsforlaget. 
Asmussen, I.H. (2014). Fra retsstat til omsorgsstat. København: DJØF.

Asmussen, I.H. (2015). Performing absolution narratives in restorative justice. Restorative Justice, 3(1), 28-48.

Asp, P. \& Ulväng, M. (2014). Straffrätt: en kortfattad översikt. Uppsala: Iustus.

Backer, F. (1990). Ankeordningen i straffesaker. I N. Christie, A. Kjønstad, P. Lødrup, S. Slet$\tan \&$ C. Smith (Red.), ... den urett som ikke rammer deg selv. Festskrift til Anders Bratholm 70 år. Oslo: Universitetsforlaget.

Balvig, F., Helgi Gunnlaugsson, Jerre, K., Olaussen, L.P. \& Tham, H. (2010). Den nordiske retsbevidsthedsundersøgelse. Nordisk Tidsskrift for Kriminalvidenskab, 97(3), 232-250.

Balvig, F., Helgi Gunnlaugsson \& Tham, H. (2011). Ikke kun strenghed - replik om de nordiske retsbevissthedsundersøgelser. Nordisk Tidsskrift for Kriminalvidenskab, 98(3), 228-238.

Bjarup, J. (2014). Bokanmeldelse: Jens Evald: Alf Ross: et liv. Tidsskrift for Rettsvitenskap, 127(2), 268-285.

Blume, P. (2011). Ross - for altid? Juristen(1), 29-31.

Boucht, J. \& Frände, D. (2007). Finsk straffrätt: grundkurs $i$ straffrättens allmänna läror. Helsinki: Polisskolan.

Bowles, S. \& Polania-Reyes, S. (2012). Economic Incentives and Social Preferences: Substitutes or Complements? Journal of Economic Literature, 50(2), 368-425.

Christie, N. (1977a). Conflicts as property. British Journal of Criminology, 17(1), 1-15.

Christie, N. (1977b). Konflikt som eiendom. Tidsskrift for Rettsvitenskap, 91, 113-132.

Christie, N. (1993). Crime control as industry: towards gulags, Western style? London; New York: Routledge.

Christie, N. (2013). Conflicts as Property [extract]. I G. Johnstone (Red.), A Restorative justice reader: texts, sources, context (2. utg., s. 36-46). Abingdon: Routledge.

Christie, N. (2015). Widening the net. Restorative Justice, 3(1), 109-113.

Cornwell, D.J., Blad, J. \& Wright, M. (Red.). (2013). Civilising criminal justice: an international restorative agenda for penal reform. Hook: Waterside Press.

Coward, K. (2015). Tanker om straffutmåling - etter 16 år i Høyesterett. Jussens Venner, 50(12), 81-88.

Cunneen, C. \& Hoyle, C. (2010). Debating restorative justice. Oxford: Hart Publishing.

Danielsen, S. (1994). Arv og forbrydelse. I T. Håstad, P.H. Lindblom \& Å. Saldeen (Red.), Festskrift till Anders Agell (s. 91-111). Uppsala: Iustus.

Dervan, L.E. \& Edkins, V.A. (2013). The Innocent Defendant's Dilemma: An Innovative Empirical Study of Plea Bargaining's Innocence Problem. Journal of Criminal Law and Criminology, 103(1), 1-48.

Elholm, T. (2010). 8:13 - om bøder og proportionalitet i specialstrafferetten. København: Jurist- og Økonomforbundets Forlag.

Elholm, T. (2011). Rimer signal på kriminal? - Om symbol- og signallovgivning i dansk kriminalpolitisk perspektiv. I U. Andersson, C. Wong \& H. Örnemark Hansen (Red.), Festskrift till Per Ole Träskman (s. 166-178). Stockholm: Norstedts Juridik.

Evald, J. (2010). Alf Ross: Et liv. København: Jurist- og Økonomforbundets Forlag.

Eyben, W.E. v. (1950). Strafudmåling: lovens rammer og dommerens udfylding. København: Gad. 
Fougner, J. (2011). Oppsigelse på grunn av fengsling - risiko for fravær og skyldspørsmål. I O.H. Rønning (Red.), Med loven mot makta - Jubileumsskrift til Juss-Buss (s. 171-186). Oslo: Novus.

Frøseth, A.M., Gröning, L. \& Wandall, R. (Red.). (2016). Rettsfølelsen i strafferettssystemet perspektiver fra teori og praksis. Oslo: Gyldendal Rettsdata.

Gröning, L., Husabø, E.J. \& Jacobsen, J. (2015). Frihet, forbrytelse og straff: en systematisk framstilling av norsk strafferett. Foreløpig versjon av del I og II. Bergen: Fagbokforlaget.

Gröning, L. \& Jacobsen, J. (Red.). (2012). Restorative justice and criminal justice: Exploring the relationship. Stockholm: Santérus.

Halvorsen, V. (2014). Nils Christie: «Conflicts as Property». I M.D. Dubber (Red.), Foundational texts in modern criminal law (s. 335-352). Oxford: Oxford University Press.

Hauge, R. (2002). Straffelovgivningens utvikling gjennom 100 år. Tidsskrift for Strafferett, 2(4), 338-344.

Heffermehl, A. (2002). Straffelovkommisjonens delutredning VII, NOU 2002: 4 Ny straffelov. Tidsskrift for Strafferett, 2(2), 135-161.

Holmboe, M. (2004a). Samfunnsstraff i nyere rettspraksis - en oversikt. Lov og Rett, 43(9), 532552.

Holmboe, M. (2004b). Ungdom, fart og samfunnsstraff - noe om utviklingen i rettspraksis. Tidsskrift for Strafferett, 4(1), 44-52.

Holmboe, M. (2011). Straffutmålingsfrafall og påtaleunnlatelse for uaktsom forvoldelse av nærståendes død. Tidsskrift for Strafferett, 11(4), 401-418.

Holmboe, M. (2014). Ungdomsstraff og ungdomsoppfølging: En oversikt og noen kritiske merknader. Tidsskrift for Strafferett, 14(4), 397-414.

Holmboe, M. (2016a). Fengsel eller frihet: Om teori og praksis $i$ norsk straffutmåling, scerlig $i$ grenselandet mellom fengsel og mildere reaksjoner. (ph.d.-avhandling), Universitetet i Oslo, Oslo. (93)

Holmboe, M. (2016b). Ytring: Om «samfunnsnyttige oppgaver» i ungdomsplaner. Behov for reform? Tidsskrift for Strafferett, 16(1), 3-7.

Holmboe, M. (2016c). Konfliktrådsloven med kommentarer. Oslo: Universitetsforlaget (under utgivelse).

Husabø, E.J. (1994). Anke i straffesaker etter to-instansordninga. Lov og Rett, (33), 9, 515-530.

Høgetveit, E. (2002). Hovedlinjer i Straffelovkommisjonens utkast til ny straffelov. Tidsskrift for Strafferett, 2(4), 360-370.

Iversen, J.S. (2013a). En kritikk av ungdomsstraffen. Lov og Rett, 52(9), 630-639.

Iversen, J.S. (2013b). Ungdomsstraff og menneskerettigheter. Tidsskrift for Strafferett, 13(3), 377-395.

Jareborg, N. (1992). Straffrättsideologiska fragment. Uppsala: Universitetet i Uppsala.

Jareborg, N. (2006). Alf Ross som straffrättsdogmatiker Inkast i straffområdet (s. 110-121). Uppsala: Iustus.

Jareborg, N. \& Zila, J. (2010). Straffrättens påföljdslära (3. utg.). Stockholm: Norstedts juridik.

Jerre, K. (2013a). The Public's Sense of Justice in Sweden - a Smorgasbord of Opinions. (Doktoravhandling), Department of Criminology, Stockholm University, Stockholm.

Jerre, K. (2013b). Public Opinion on Appropriate Sentences - which Public, which Opinion? European Journal on Criminal Policy and Research, 19(1), 31-45. 
Johnstone, G. (2011). Restorative Justice: Ideas, values, debates (2. utg.). London: Routledge.

Kinander, M. (2013). Straffens begrep og begrunnelse i norsk rett - en kritikk. Jussens Venner, 48(3), 155-192.

Langbein, J.H. (1978). Torture and Plea Bargaining. The University of Chicago Law Review, 46(1), 3-22.

Lie, E.M. (2015). I forkant: Kriminalitetsforebyggende politiarbeid (2. utg.). Oslo: Gyldendal akademisk.

Lånke, T.K. (2008). Straffutmålingsfrafall etter straffeloven av $2005 \S 61$. Tidsskrift for Strafferett, $8(2), 145-178$.

Matningsdal, M. (1996). To-instansreformen. Oslo: Universitetsforlaget.

Matningsdal, M. (2006). Høyesterett som straffedomstol etter to-instansreformen. Lov og Rett, 45(9), 429-458.

Matningsdal, M. (2010). Norsk spesiell strafferett. Bergen: Fagbokforlaget.

Matningsdal, M. (2015a). Høyesterett som straffedomstol - straffutmåling. I T. Schei, J.E.A. Skoghøy \& T.M. Øie (Red.), Lov, sannhet, rett: Norges Høyesterett 200 år (s. 548-595). Oslo: Universitetsforlaget.

Matningsdal, M. (2015b). Nytt i ny straffelov. Oslo: Universitetsforlaget.

Matningsdal, M. (2015c). Straffeloven: Alminnelige bestemmelser. Kommentarutgave. Oslo: Universitetsforlaget.

Midbøe, F.B. (1960). Bøtestraff og subsidicer fengselsstraff: en undersøkelse av avsoningsrisikoen for bøter i norsk strafferettspleie. Oslo: Universitetsforlaget.

Myhrer, T.-G. (2008). Ny straffelov. Jussens venner, 43(2), 95-135.

Myhrer, T.-G. (2011). Mulige forebyggende virkninger av straffen - generelt og overfor terrorhandlinger spesielt. I T. Bjørgo (Red.), Forebygging av terrorisme og annen kriminalitet (s. 83-106). Oslo: Politihøgskolen.

Nelson, A. (1990). Den rättvisa brottspåföljden. I N. Christie, A. Kjønstad, P. Lødrup, S. Slettan \& C. Smith (Red.), ... den urett som ikke rammer deg selv. Festskrift til Anders Bratholm 70 år (s. 73-86). Oslo: Universitetsforlaget.

Nymo, K. (2015). Hvorfor straffer vi - egentlig? Tidsskrift for Strafferett, 15(3), 287-314.

Olaussen, L.P. (2011). De nordiske rettsbevisshetsundersøkelsene - noen metodekritiske betraktninger. Nordisk Tidsskrift for Kriminalvidenskab, 98(3), 209-227.

Olaussen, L.P. (2013). Hva synes folk om straffenivået?: en empirisk undersøkelse. Oslo: Novus.

Rawls, J. (1955). Two concepts of rules. Philosophical Review, 64(1), 3-32.

Ross, A. (1969). «Straffens formål». Tidsskrift for Rettsvitenskap, 82(4), 391-430.

Ross, A. (1971). Endnu en gang «straffens formål». Tidsskrift for Rettsvitenskap, 84(4), 390398.

Rui, J.P. (2014). Straffeprosessen i perspektiv. Jussens Venner, 49(6), 382-443.

Ryberg, J. \& Roberts, J.V. (Red.). (2014). Popular Punishment: On the Normative Significance of Public Opinion: Oxford University Press.

Scherger, V. (2015). Ungdomsstraffen - en fare for barns rettssikkerhet? Kritisk juss, 41(2), 87104.

Stridbeck, U. (2010). Hensynet til den alminnelige rettsfølelse ved straffutmåling. Tidsskrift for Strafferett, 10(3), 207-209. 
Stridbeck, U. (2015). Falske tilståelser. I P. Grøndahl \& U. Stridbeck (Red.), Rettspsykiatriske beretninger: Om sakkyndighet og menneskeskjebner (s. 255-272). Oslo: Gyldendal Akademisk.

Warner, K. \& Davis, J. (2012). Using Jurors to Explore Public Attitudes to Sentencing. British Journal of Criminology, 52(1), 93-112.

Zehr, H. (2008). Genopprettende ret: en lille bog om ret, uret og retfcerdighed (J.B. Rosenberg, Overs.). København: Akademisk Forlag.

Forarbeider, stortingsdokumenter og offentlige utredninger

Innst. O. nr. 45 (2000-2001). Innstilling fra justiskomiteen om lov om endringer $i$ straffeloven og straffeprosessloven (bruken av varetektsfengsling $m v$.).

Innst. O. nr. 72 (2004-2005). Innstilling fra justiskomiteen om lov om straff (straffeloven).

NOU 1992: 28. To-instansbehandling, anke og juryordning $i$ straffesaker.

NOU 2014: 1. Ny arvelov.

Ot.prp. nr. 8 (2007-2008). Om lov om endringer i straffeloven 20. mai $2005 \mathrm{nr} .28 \mathrm{mv}$. (skjerpende og formildende omstendigheter, folkemord, rikets selvstendighet, terrorhandlinger, ro, orden og sikkerhet, og offentlig myndighet).

Ot.prp. nr. 22 (2008-2009). Om lov om endringer i straffeloven 20. mai 2005 nr. 28 (siste delproposisjon - sluttføring av spesiell del og tilpasning av annen lovgivning).

Ot.prp. nr. 81 (1999-2000). Om lov om endringer i straffeloven og straffeprosessloven (bruken av varetektsfengsling $m v$.).

Ot.prp. nr. 90 (2003-2004). Om lov om straff (straffeloven).

Prop. 57 L (2013-2014). Lov om konfliktrådsbehandling (konfliktrådsloven).

Prop. 64 L (2014-2015). Lov om ikraftsetting av straffeloven 2005 (straffelovens ikraftsettingslov).

Prop. 97 L (2009-2010). Endringer i straffeloven 1902 mv. (skjerping av straffen for drap, annen grov vold og seksuallovbrudd).

Prop. 135 L (2010-2011). Endringer i straffeloven, straffeprosessloven, straffegjennomføringsloven, konfliktrådsloven m.fl. (barn og straff).

St.meld. nr. 104 (1977-78). Om kriminaliteten.

Statistisk Sentralbyrå. (2015). Tabell: 10560: Løslatelser, etter type fengsling, anstalttid og alder. Absolutte tall. 